\title{
Can Stem Cells Improve Left Ventricular Ejection Fraction in Heart Failure? A Literature Review of Skeletal Myoblasts and Bone Marrow-Derived Cells
}

\author{
Meghan M. Cheung ${ }^{1}$, Nusrat Jahan ${ }^{2}$ \\ 1. Family Medicine, California Institute of Behavioral Neurosciences \& Psychology, Fairfield, USA 2. Internal Medicine, \\ California Institute of Behavioral Neurosciences \& Psychology, Fairfield, USA
}

Corresponding author: Meghan M. Cheung, meghanmcheung@gmail.com

\begin{abstract}
Heart failure is a life-threatening condition that affects millions worldwide and is only expected to get worse with an ageing population. Current treatment regimens rely on medical therapy and heart transplantation as a last resort. Stem cells have been undergoing clinical trials worldwide as a hope for a new and safe clinical treatment. Skeletal myoblasts and bone marrow-derived stem cells are two types of stem cells being tested. The objective is to evaluate the efficacy of these two types of stem cells for heart failure therapy. Data were searched in PubMed using both regular and Medical Subject Heading (MeSH) keywords (stem cells, therapy, heart failure) and then filtered using inclusion/exclusion criteria (language, species, publication date, and age). In total, 31 research articles were reviewed (14 clinical trials, four randomized control trials, nine review articles, one case report, one comparative study, one systematic review, and one categorized as a systematic review and meta-analysis). Both skeletal myoblasts and bone marrow-derived stem cells showed mixed results in improving left ventricular ejection fraction in heart failure patients in the majority of studies. Larger studies need to be done to further investigate the efficacy of stem cells as a therapy for heart failure.
\end{abstract}

Received 10/19/2020 Review began 11/04/2020 Review ended 11/08/2020 Published 11/20/2020

(c) Copyright 2020 Cheung et al. This is an open access article distributed under the terms of the Creative Commons Attribution License CC-BY 4.0., which permits unrestricted use, distribution, and reproduction in any medium, provided the original author and source are credited.
Categories: Cardiology, Family/General Practice, Internal Medicine

Keywords: heart failure, heart failure therapy, left ventricular ejection fraction, bone marrow, stem cell therapy, skeletal myoblasts, bone marrow derived stem cells, stem cells transplantation, cd34+, stem cells

\section{Introduction And Background}

With approximately 26 million people diagnosed worldwide, heart failure has become an ever-increasing strain and burden on the healthcare system and on society. With an ageing population and no cure, this number is only expected to increase [1]. Heart failure is a life-threatening clinical condition where damage to the heart causes problems in ventricular filling or in the ejection of blood. Common clinical symptoms include dyspnea, fatigue, and edema. Left ventricular ejection fraction (LVEF) can show the functional status of the heart and be used to clinically classify heart failure. A reduced LVEF and an LVEF < $45 \%$ are predictors of poor outcome and increased mortality in an inpatient setting, respectively [2]. A common classification used for heart failure is the New York Heart Association functional classification: NYHA I (no limitations to physical activity), NYHA II (mild symptoms to ordinary physical activity), NYHA III (comfortable at rest, marked symptoms with less than ordinary activity), and NYHA IV (severe limitations, symptoms at rest) [2].

Management of heart failure is primarily in the form of drug therapy with the aim of improving prognosis and symptoms and reducing mortality and morbidity. Medical management depends on patient history along with signs and symptoms of heart failure and includes diuretics, angiotensin-converting enzyme inhibitors or angiotensin receptor blockers, beta-adrenergic blockers, aldosterone antagonists, digoxin, anticoagulants, and inotropic agents [2]. For those who are refractory to medical treatment and develop endstage heart failure, left ventricular assist system and heart transplantation are options but have limitations due to organ donation. With heart transplantation being the only definitive treatment, new therapies are continually being researched [3].

Stem cells have been an emerging trend in the research of heart failure treatment as they have the ability for self-renewal and have the potential to differentiate into different tissue types [4]. Stem cell therapy has the potential to replace and rebuild damaged myocardium and improve its function through neovascularization and the prevention of myocardial cell death [5].

Hope that one day stem cells will be a safe and efficient way to treat heart failure and improve the quality of life of patients, reduce mortality and morbidity, and decrease the global burden of this disease. For the practical application of stem cells to be clinically useful, a myriad of research must be done as there are many factors that need to be considered. Factors that need to be investigated and have been undergoing research are the type of stem cells used, application of the stem cells, dose, concentration, timing, patient 


\section{Cureus}

population, and adverse outcomes. Safety concerns with regard to stem cell therapy in the myocardium are most related to increased incidence of ventricular arrhythmias [5]. While there has been much anticipation for the application of stem cells, research has so far been mixed. Skeletal myoblasts and bone marrowderived stem cells are two common types of stem cells in heart failure therapy that are studied $[4,5]$. This literature review will focus on skeletal myoblasts and bone marrow-derived stem cells in improving LVEF in patients with heart failure.

\section{Review}

\section{Search strategy}

Data for this review article were searched on PubMed using both regular and Medical Subject Heading (MeSH) keywords. The following keywords were used: stem cells, therapy, and heart failure. Search results were then narrowed down using inclusion/exclusion criteria. These criteria were based on language, species, year of publication, and subject age. Table 1 illustrates the search terms and the inclusion/exclusion criteria used along with the number of articles found. The inclusion/exclusion criteria were applied in the order that they appear in Table 1.

\begin{tabular}{lc}
\hline Criteria Used & Numb \\
\hline Regular Keywords - Stem Cells, Therapy, Heart Failure & 2423 \\
Inclusion/Exclusion Criteria & 2261 \\
English Language & 1648 \\
Human Species & 501 \\
Published Within 5 Years & 97 \\
Aged 19+ & 371 \\
MeSH Keywords - Stem Cells, Therapy, Heart Failure & \\
Inclusion/Exclusion Criteria & 335 \\
English Language & 275 \\
Human Species & 143 \\
Published Within 10 Years &
\end{tabular}

TABLE 1: Regular and MeSH Keywords and Inclusion/Exclusion Criteria Used in Literature Search MeSH: Medical Subject Heading

\section{Search result}

A total of 2794 research articles was found using both the regular and MeSH keywords. After the results were filtered using the inclusion/exclusion criteria, a total of 240 articles remained. All 240 articles were reviewed and 208 were removed for the following reasons: duplication of articles (12), focused on a disease other than that of interest, and full text not freely available.

An additional four articles were manually selected through reviewing references of the selected articles. In total, 31 articles were reviewed and classified as follows: 14 were clinical trials, four were randomized control trials, nine were review articles, one was a systematic review, one was a case report, one was a comparative study and one was described as both a meta-analysis and systematic review. The minimum number of subjects in a study was one and the maximum was 2939 and the total number of subjects in the 31 reviewed articles was 5154 . The process of data collection is shown below in the preferred reporting items for systematic reviews and meta-analyses (PRISMA) flow diagram in Figure 1 [6]. 


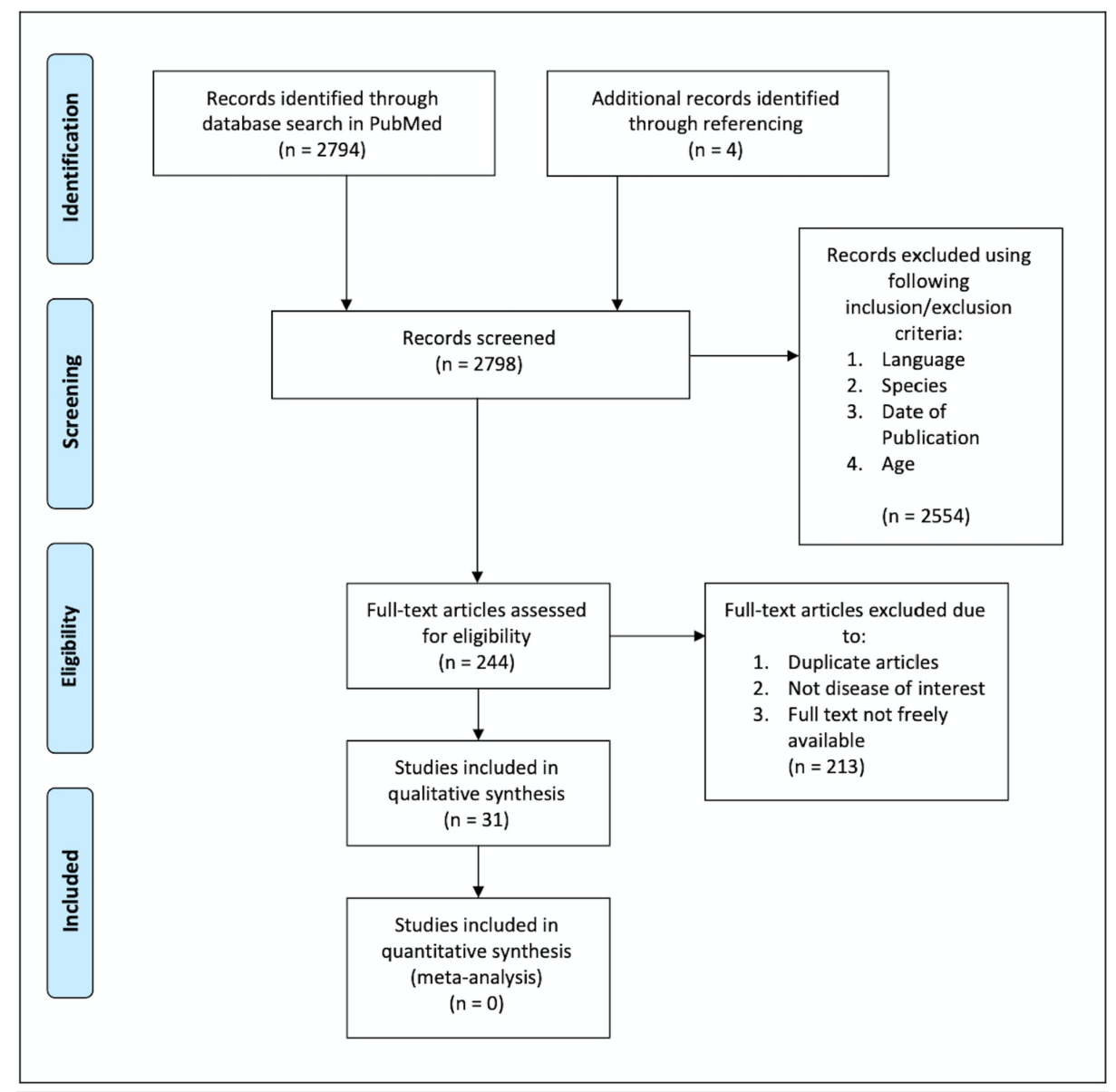

FIGURE 1: PRISMA Flow Diagram of Topic Search Results and Article Selection Process

PRISMA: preferred reporting items for systematic reviews and meta-analyses

\section{Discussion}

After analysis of all data, it was found that neither type of stem cell has an overall positive effect in increasing LVEF. A total of six randomized control trials and five clinical trials involving either skeletal myoblast or bone marrow-derived stem cells for implantation in the myocardium of patients with heart failure were analyzed and tabulated. Other clinical trials that were analyzed examined repeated stem cell injection and stem cell transplantation in subjects with diabetes or insulin resistance. Two systematic reviews were also investigated to study the efficacy of stem cell therapy. It should be noted that while the studies used many endpoints to evaluate the effectiveness of their trial, this literature review focused on LVEF.

Two groups of stem cells being studied with regard to heart failure are multipotent stem cells (adult stem cells) and pluripotent stem cells (embryonic stem cells or induced pluripotent stem cells). Multipotent stem cells can be isolated from various tissues such as skeletal muscle, adipose tissue, and peripheral blood or the bone marrow. An advantage of adult stem cells is that they can be used in autologous transplantation making them more accessible and without risk of immunological rejection [7]. Along with ethical and regulatory issues arising when dealing with embryonic cells, there is also the risk of malignancies occurring after implantation and for this reason, other types of stem cells remain a more attractive option [4].

The tables below show clinical trials that have been performed in ischemic and non-ischemic heart failure using either skeletal myoblasts or bone marrow-derived cells. The patient population for these trials was chosen using criteria such as LVEF and NYHA class.

\section{Skeletal myoblasts}

As mentioned before, skeletal myoblasts are an accessible source of autologous cells. They have also been shown to be resistant to ischemia, inflammation, and oxidative stress and able to form new myotubules in scarred myocardium in animal models [8]. As a result, skeletal myoblasts have been mostly studied in 


\section{Cureus}

ischemic heart failure. Table 2 illustrates clinical trials that have studied the effects of skeletal myoblasts in heart failure.

\begin{tabular}{|c|c|c|c|c|c|}
\hline Author/Year & $\begin{array}{l}\text { Type of } \\
\text { Study }\end{array}$ & Cells Used & Patient Population & $\begin{array}{l}\text { Sample } \\
\text { Size }\end{array}$ & Change in LVEF \\
\hline $\begin{array}{l}\text { Duckers et } \\
\text { al., } 2011 \text { [8] }\end{array}$ & $\begin{array}{l}\text { Clinical } \\
\text { trial }\end{array}$ & $\begin{array}{l}\text { Autologous skeletal } \\
\text { myoblasts from quadriceps } \\
\text { or gastrocnemius }\end{array}$ & $\begin{array}{l}\text { Ischemic Cardiomyopathy with } \\
\text { clinically manifest HF, LVEF = } 20-45 \% \text {, } \\
\text { NYHA class II-III }\end{array}$ & 47 & $\begin{array}{l}\text { LVEF at } 6 \text { months not } \\
\text { statistically significant } \\
\text { compared to control }\end{array}$ \\
\hline $\begin{array}{l}\text { Brickwedel } \\
\text { et al., } 2014 \\
\text { [9] }\end{array}$ & $\begin{array}{l}\text { Clinical } \\
\text { trial }\end{array}$ & $\begin{array}{l}\text { Autologous skeletal } \\
\text { myoblasts from upper thigh }\end{array}$ & $\begin{array}{l}\text { Chronic ischemic heart disease with } \\
\text { coronary artery bypass operation } \\
\text { indicated, LVEF }=15-35 \% \text {, NYHA class } \\
\text { I-IV }\end{array}$ & 7 & $\begin{array}{l}\text { No significant difference } \\
\text { in LVEF across groups } \\
\text { (high dose, low dose, } \\
\text { placebo) at } 12 \text { months }\end{array}$ \\
\hline $\begin{array}{l}\text { Sawa et al., } \\
2015[3]\end{array}$ & $\begin{array}{l}\text { Clinical } \\
\text { trial (no } \\
\text { control } \\
\text { group) }\end{array}$ & $\begin{array}{l}\text { Autologous skeletal } \\
\text { myoblast sheets (TCD- } \\
\text { 51073) }\end{array}$ & $\begin{array}{l}\text { Ischemic heart disease with impaired } \\
\text { left ventricular systolic function, LVEF } \\
=35 \% \text {, NYHA class III-IV }\end{array}$ & 7 & $\begin{array}{l}\text { LVEF maintained in } 5 \\
\text { subjects and improved } \\
\text { over time at } 26 \text { weeks }\end{array}$ \\
\hline $\begin{array}{l}\text { Gwizdala et } \\
\text { al., } 2017 \text { [10] }\end{array}$ & $\begin{array}{l}\text { Clinical } \\
\text { trial (no } \\
\text { control } \\
\text { group) }\end{array}$ & $\begin{array}{l}\text { Autologous } \mathrm{Cx}-43 \text { modified } \\
\text { skeletal muscle derived } \\
\text { stem cells taken from } \\
\text { quadriceps }\end{array}$ & $\begin{array}{l}\text { Left ventricular dysfunction secondary } \\
\text { to ischemic heart disease or dilated } \\
\text { cardiomyopathy, LVEF }=40 \% \text {, NYHA } \\
\text { class III }\end{array}$ & 13 & $\begin{array}{l}\text { No significant difference } \\
\text { at } 6 \text { months }\end{array}$ \\
\hline
\end{tabular}

\section{TABLE 2: Summary of Clinical Studies Using Skeletal Myoblasts in Heart Failure}

HF: heart failure; LVEF: left ventricular heart failure; NYHA: New York Heart Association

The data collected in Table 2 show that there has not been a success in increasing LVEF from autologous skeletal myoblast transplantation into the myocardium in ischemic heart failure. Sawa et al. did show an increase in LVEF in five of the seven subjects at 26 weeks but nothing else is known beyond this time frame and it was not measured against a control group [3]. Similarly, a review article done by Rikhtegar et al. found that in the long-term follow-up of the first phase 1 cohort study in severe heart failure, LVEF was shown to steadily improve over time after injection of skeletal myoblasts during a coronary artery bypass graft [11].

\section{Bone marrow-derived cells}

Like skeletal myoblasts, the adult bone marrow can be a great source of stem cells and these cells can be readily available and accessible for autologous transplantation without immune rejection. Bone marrow contains hematopoietic stem cells, endothelial progenitor cells, mesenchymal stem cells, and cardiac stem cells. Hematopoietic stem cells and endothelial progenitor cells can be isolated from the bone marrow cells through the identification of surface antigens such as CD34 [7]. Bone marrow-derived cells are promising in stem cell therapy as they have been shown to possess antifibrotic, proangiogenic, and immunomodulatory properties that can potentially stimulate the repair of damaged tissues [12]. Table 3 shows the main findings of the studies examined with regard to bone marrow-derived stem cells. 


\section{Cureus}

\begin{tabular}{|c|c|c|c|c|c|}
\hline Author/Year & $\begin{array}{l}\text { Type of } \\
\text { Study }\end{array}$ & Cells Used & Patient Population & $\begin{array}{l}\text { Sample } \\
\text { Size }\end{array}$ & Change in LVEF \\
\hline $\begin{array}{l}\text { Lezaic et } \\
\text { al., } 2015 \text { [13] }\end{array}$ & $\begin{array}{l}\text { Clinical trial } \\
\text { (no control } \\
\text { group) }\end{array}$ & $\begin{array}{l}\text { Autologous CD34+ cells from } \\
\text { peripheral blood by } \\
\text { aphaeresis }\end{array}$ & $\begin{array}{l}\text { Non-ischemic dilated } \\
\text { cardiomyopathy, LVEF } \\
<40 \% \text {, NYHA class III }\end{array}$ & 21 & $\begin{array}{l}\text { 10/21 showed significant changes } \\
\text { in LVEF at } 5 \text { years }\end{array}$ \\
\hline $\begin{array}{l}\text { Hamshere } \\
\text { et al., } 2015 \\
\text { [14] }\end{array}$ & $\begin{array}{l}\text { Randomized } \\
\text { placebo- } \\
\text { controlled } \\
\text { trial }\end{array}$ & $\begin{array}{l}\text { Autologous bone marrow- } \\
\text { derived cells with granulocyte } \\
\text { colony-stimulating factor (G- } \\
\text { CSF) }\end{array}$ & $\begin{array}{l}\text { Non-ischemic dilated } \\
\text { cardiomyopathy, LVEF } \\
<45 \% \text {, NYHA class II-IV }\end{array}$ & 60 & $\begin{array}{l}\text { Statistically significant increase at } \\
3 \text { months and maintained at } 1 \text { year } \\
\text { in the G-CSF/bone marrow cell } \\
\text { treatment group }\end{array}$ \\
\hline $\begin{array}{l}\text { Butler et al., } \\
2016 \text { [15] }\end{array}$ & $\begin{array}{l}\text { Randomized } \\
\text { placebo- } \\
\text { controlled } \\
\text { trial }\end{array}$ & $\begin{array}{l}\text { Ischemia tolerant allogeneic } \\
\text { mesenchymal cells extracted } \\
\text { from the bone marrow of } \\
\text { young healthy volunteers }\end{array}$ & $\begin{array}{l}\text { Non-ischemic } \\
\text { cardiomyopathy, LVEF } \\
=40 \% \text {, NYHA class II-III }\end{array}$ & 23 & $\begin{array}{l}\text { No significant difference between } \\
\text { groups at } 90 \text { days }\end{array}$ \\
\hline $\begin{array}{l}\text { Bervar et } \\
\text { al., } 2017 \text { [16] }\end{array}$ & Clinical trial & $\begin{array}{l}\text { Autologous CD } 34+\text { cells from } \\
\text { peripheral blood by } \\
\text { aphaeresis }\end{array}$ & $\begin{array}{l}\text { Non-ischemic } \\
\text { cardiomyopathy, LVEF } \\
<40 \% \text {, NYHA class III }\end{array}$ & 38 & $\begin{array}{l}\text { No significant differences between } \\
\text { groups at } 1,3,6 \text {, and } 12 \text { months } \\
\text { (groups based on diastolic } \\
\text { dysfunction with estimated filling } \\
\text { pressures }>/<15 \text { ) }\end{array}$ \\
\hline $\begin{array}{l}\text { Teerlink et } \\
\text { al., } 2017 \text { [17] }\end{array}$ & $\begin{array}{l}\text { Randomized } \\
\text { control trial } \\
\text { (post hoc } \\
\text { analysis) }\end{array}$ & $\begin{array}{l}\text { Autologous mesenchymal } \\
\text { bone marrow stem cells } \\
\text { aspirated from the iliac crest }\end{array}$ & $\begin{array}{l}\text { Chronic heart failure } \\
\text { secondary to ischemic } \\
\text { heart disease, LVEF < } \\
35 \%, \text { NYHA class II-IV }\end{array}$ & 315 & $\begin{array}{l}\text { No significant differences found in } \\
\text { LVEF between groups at } 1 \text { year }\end{array}$ \\
\hline $\begin{array}{l}\text { Mostafavian } \\
\text { et al., } 2018 \\
{[18]}\end{array}$ & Clinical trial & $\begin{array}{l}\text { Autologous mononuclear } \\
\text { cells of bone marrow } \\
\text { aspirated }\end{array}$ & $\begin{array}{l}\text { Chronic heart failure, } \\
\text { LVEF }=40 \%, \text { NYHA } \\
\text { class II-IV }\end{array}$ & 60 & $\begin{array}{l}\text { No significant difference between } \\
\text { groups (treatment vs. control) at } 3 \\
\text { months }\end{array}$ \\
\hline
\end{tabular}

\section{TABLE 3: Summary of Clinical Studies Using Bone Marrow-Derived Cells in Heart Failure}

LVEF: left ventricular ejection fraction; NYHA: New York Heart Association

The bone marrow-derived stem cell studies examined show slightly better outcomes compared to skeletal myoblast trials but were still unremarkable as a whole. Two of the studies were able to show improvement of LVEF > 5\% at follow up. Lezaic et al. concluded that the results for the clinical trial showed improvement in $48 \%$ of their subjects at five-year follow-up but one of the limitations of the study was that they were not compared to a control group [13]. Hamshere et al. also saw a significant increase in LVEF at three-month follow-up and this increase was maintained at one year [14]. Similarly, in a post hoc analysis of three-phase 1/11 clinical trials, it was found that bone marrow-derived cells in patients with non-ischemic dilated cardiomyopathy showed significant improvements in LVEF at 12 months both within their study group and compared to those with ischemic cardiomyopathy [12].

In addition to the studies in Table 3, two clinical trials using CD34+ peripheral blood cells in non-ischemic dilated cardiomyopathy were reviewed. These studies focused on repetitive injections and in diabetic and insulin-resistant patients, respectively. In the first study, results showed significant improvement in LVEF at six months having one dose but did not show further improvement at one year after a second dose was injected compared to the single-dose group [19]. In the second study, the patients with insulin resistance and no insulin resistance had a significant increase in LVEF while the diabetes group showed no improvement at six-month follow-up. It was noted that a higher dose of cells needed to be injected in the insulin-resistant patients for similar outcomes to the non-insulin resistant group showing a reduced efficacy in insulin resistance. Another important point was that the diabetic patients had more advanced heart failure than their counterparts. Whether the diabetes, the more advanced heart failure, or the combination of both played a role in seeing no change in LVEF will have to be further studied [20].

A systematic review that examined adult stem cell therapy studies between 2000 and 2016 found similar mixed results. One of these studies is the transplantation of progenitor cells and recovery of LV function in patients with chronic ischemic heart disease (TOPCARE-CHD) study, that showed significant improvement in LVEF at three months in ischemic cardiomyopathy using bone marrow-derived cells compared to circulating progenitor cells and placebo, but these results could not be replicated in a second study. Another one is the first mononuclear cells injected in the United States conducted by the cardiovascular cell therapy research network (FOCUS-CCTRN) study that also failed to show a significant increase in LVEF at six months after bone marrow-derived cell delivery [21]. This systematic review also examined a meta-analysis that 
included 23 randomized control trials using autologous bone marrow-derived cell delivery in ischemic cardiomyopathy also found no benefits at 12 months [21]. However, a study using autologous CD34+ cell transplantation in non-ischemic cardiomyopathy found a significant improvement in LVEF at both one and five years [21]. In a separate systematic review and meta-analysis, autologous bone marrow-derived stem cells did not prove effective in increasing LVEF in ischemic heart failure when compared to a control group [22].

Although there have been mixed results with studies showing LVEF improvement, it was found that there does not seem to be a significant increase in ventricular arrhythmias and these stem cells could be safely transplanted with regard to both skeletal myoblasts and bone marrow-derived cells [21,22]. While some of these results were discouraging it must be noted that the clinical trials were limited in size. The number of study data was also limited due to the inclusion/exclusion criteria used in the study method. Another reason for the discrepancy in results is that all trials are not created equal. There is a multitude of factors that are involved in these studies such as the cell source, cell type, cell application (dose, concentration, timing), and characteristics of the patient population. Study endpoints and how results are reported also differ between trials. Larger and more standardized future trials should be done as these could result in more definitive answers.

\section{Conclusions}

This literature review of stem cells looked at their efficacy in increasing LVEF in heart failure patients. Skeletal myoblasts and bone marrow-derived cells are two types of stem cells that have been investigated in the treatment of heart failure. At best, mixed results were observed in the majority of studies showing that neither type of stem cell significantly improves LVEF in ischemic or non-ischemic heart failure. In order to further investigate the efficacy of stem cells in heart failure, more clinical trials with larger cohorts and endpoints should be conducted.

\section{Additional Information \\ Disclosures}

Conflicts of interest: In compliance with the ICMJE uniform disclosure form, all authors declare the following: Payment/services info: All authors have declared that no financial support was received from any organization for the submitted work. Financial relationships: All authors have declared that they have no financial relationships at present or within the previous three years with any organizations that might have an interest in the submitted work. Other relationships: All authors have declared that there are no other relationships or activities that could appear to have influenced the submitted work.

\section{References}

1. Savarese G, Lund LH: Global public health burden of heart failure . Card Fail Rev. 2017, 3:7-11. 10.15420/cfr.2016:25:2

2. Inamdar AA, Inamdar AC: Heart failure: diagnosis, management and utilization. J Clin Med. 2016, 5:62. 10.3390/jcm5070062

3. Sawa Y, Yoshikawa Y, Toda K, et al.: Safety and efficacy of autologous skeletal myoblast sheets (TCD-51073) for the treatment of severe chronic heart failure due to ischemic heart disease. Circ J. 2015, 79:991-999. 10.1253/circj.CJ-15-0243

4. Ghodsizad A, Ruhparwar A, Bordel V, et al.: Clinical application of adult stem cells for therapy for cardiac disease. Cardiovasc Ther. 2013, 31:323-334. 10.1111/1755-5922.12032

5. Tehzeeb J, Manzoor A, Ahmed MM: Is stem cell therapy an answer to heart failure: a literature search . Cureus. 2019, 11:5959. 10.7759/cureus.5959

6. Moher D, Liberati A, Tetzlaff J, Altman DG, The PRISMA Group: Preferred reporting items for systematic reviews and meta-analyses: the PRISMA statement. PLoS Med. 2009, 6:1000097. 10.1371/journal.pmed.1000097

7. Liao SY, Tse HF: Multipotent (adult) and pluripotent stem cells for heart regeneration: what are the pros and cons?. Stem Cell Res Ther. 2013, 4:151. 10.1186/scrt381

8. Duckers HJ, Houtgraaf J, Hehrlein C, et al.: Final results of a phase IIa, randomised, open-label trial to evaluate the percutaneous intramyocardial transplantation of autologous skeletal myoblasts in congestive heart failure patients: the SEISMIC trial. EuroIntervention. 2011, 6:805-812.

9. Brickwedel J, Gulbins H, Reichenspurner H: Long-term follow-up after autologous skeletal myoblast transplantation in ischaemic heart disease. Interact Cardiovasc Thorac Surg. 2014, 18:61-66. 10.1093/icvts/ivt434

10. Gwizdala A, Rozwadowska N, Kolanowski TJ, et al.: Safety, feasibility and effectiveness of first in-human administration of muscle-derived stem/progenitor cells modified with connexin- 43 gene for treatment of advanced chronic heart failure. Eur J Heart Fail. 2017, 19:148-157. 10.1002/ejhf.700

11. Rikhtegar R, Pezeshkian M, Dolati S, et al.: Stem cells as therapy for heart disease: iPSCs, ESCs, CSCs, and skeletal myoblasts. Biomed Pharmacother. 2019, 109:304-313. 10.1016/j.biopha.2018.10.065

12. Tompkins BA, Rieger AC, Florea V, et al.: Comparison of mesenchymal stem cell efficacy in ischemic versus nonischemic dilated cardiomyopathy. J Am Heart Assoc. 2018, 7:008460. 10.1161/JAHA.117.008460

13. Lezaic L, Socan A, Poglajen G, et al.: Intracoronary transplantation of CD34(+) cells is associated with improved myocardial perfusion in patients with nonischemic dilated cardiomyopathy. J Card Fail. 2015, 21:145-152. 10.1016/j.cardfail.2014.11.005 
14. Hamshere S, Arnous S, Choudhury T, et al.: Randomized trial of combination cytokine and adult autologous bone marrow progenitor cell administration in patients with non-ischaemic dilated cardiomyopathy: the REGENERATE-DCM clinical trial. Eur Heart J. 2015, 36:3061-3069. 10.1093/eurheartj/ehv390

15. Butler J, Epstein SE, Greene SJ, et al.: Intravenous allogeneic mesenchymal stem cells for nonischemic cardiomyopathy: safety and efficacy results of a phase II-A randomized trial. Circ Res. 2017, 120:332-340. 10.1161/CIRCRESAHA.116.309717

16. Bervar M, Kozelj M, Poglajen G, et al.: Effects of transendocardial CD34+ cell transplantation on diastolic parameters in patients with nonischemic dilated cardiomyopathy. Stem Cells Transl Med. 2017, 6:15151521. 10.1002/sctm.16-0331

17. Teerlink JR, Metra M, Filippatos GS, et al.: Benefit of cardiopoietic mesenchymal stem cell therapy on left ventricular remodelling: results from the congestive heart failure cardiopoietic regenerative therapy (CHART-1) study. Eur J Heart Fail. 2017, 19:1520-1529. 10.1002/ejhf.898

18. Mostafavian Z, Vakilian F, Torkmanzade L, Moghiman T: Effect of stem cell therapy on patients' quality of life in heart failure with reduced ejection fraction. J Med Life. 2018, 11:359-364.

19. Vrtovec B, Poglajen G, Sever M, et al.: Effects of repetitive transendocardial CD34+ cell transplantation in patients with nonischemic dilated cardiomyopathy. Circ Res. 2018, 123:389-396. 10.1161/CIRCRESAHA. 117.312170

20. Vrtovec B, Sever M, Jensterle M, et al.: Efficacy of CD34+ stem cell therapy in nonischemic dilated cardiomyopathy is absent in patients with diabetes but preserved in patients with insulin resistance. Stem Cells Transl Med. 2016, 5:632-638. 10.5966/sctm.2015-0172

21. Nguyen PK, Rhee JW, Wu JC: Adult stem cell therapy and heart failure, 2000 to 2016: a systematic review . JAMA Cardiol. 2016, 1:831-841. 10.1001/jamacardio.2016.2225

22. Lalu MM, Mazzarello S, Zlepnig J, et al.: Safety and efficacy of adult stem cell therapy for acute myocardial infarction and ischemic heart failure (SafeCell Heart): a systematic review and meta-analysis. Stem Cells Transl Med. 2018, 7:857-866. 10.1002/sctm.18-0120 